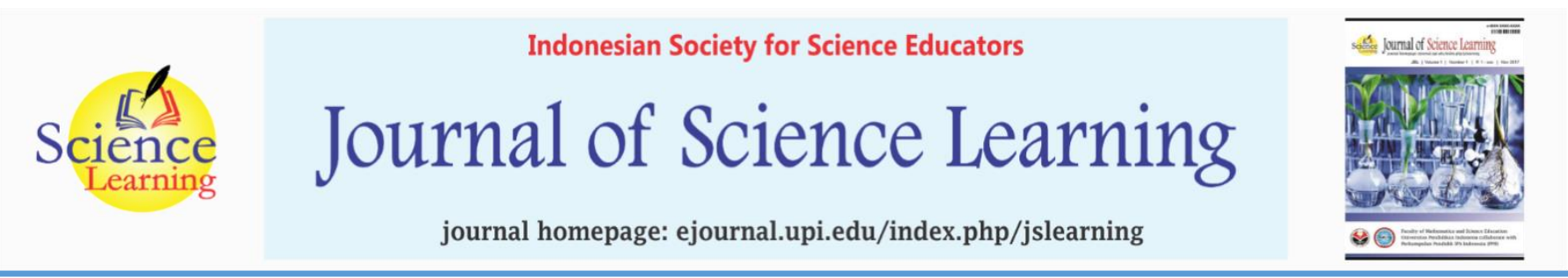

\title{
STEM-Focused Activities to Support Student Learning in Primary School Science
}

\section{Neslihan Ültay ${ }^{*}$, Arzu Zıvalı1, Hilal Yılmaz ${ }^{1}$, Hilal K. Bak¹, Kezban Yılmaz' ${ }^{1}$, Melek Topatan¹, Pelin Gül Kara ${ }^{1}$}

${ }^{1}$ Department of Elementary Education, Faculty of Education, Giresun University, Giresun, Turkey

*Corresponding Author neslihan.ultay@giresun.edu.tr

\begin{abstract}
This study examines the effect on student academic success through teaching the "Let's Know the Matter" grade 3 science unit accompanied by STEM (Science, Technology, Engineering, and Mathematics)-focused activities. The study group consisted of 24 third grade students studying in the 20192020 academic year. Teaching was done with a 5E (enter, explore, explain, elaborate, evaluate) instructional model, and student opinions about the STEM activities were collected. A group pretest-posttest research design was used in which the "Let's Know the Matter Test (MT)" was administered at the beginning to measure the students' prior knowledge, and again at the end of the unit to determine what students had learned. Their opinions of the lessons taught with STEM-focused activities were collected using a semistructured interview technique. Qualitative data were divided into appropriate categories under common themes. It was observed that the $5 \mathrm{E}$ instructional model contributed to their academic success. Also, it was found that their opinions about the lessons taught with STEM activities were quite positive. Based on the results obtained from the research, it is suggested that STEM activities be used in the teaching of other topics.
\end{abstract}

Keywords Matter, Primary school, STEM, Third graders

\section{INTRODUCTION}

In the 21st century, the field of technology and engineering is developing and changing rapidly. As a result of the reflection of these changes to education, technology, and engineering fields have become an integral part of education. This situation increases the need for renewal studies in education. One of the new approaches of the 21 st century is STEM education. STEM acronym is a teaching and learning approach consisting of the initials of the words science, technology, engineering, mathematics. STEM helps to teach students science, mathematics, engineering, and technology together, and it enables students to transfer what has been learned to live. The concept of STEM was first expressed by the National Science Foundation Education Director Judith Ramalev in 2001 (Sanders, 2009; Yildırm \& Altun, 2015).

STEM education can be described as the change of integrated education, which does not require the division of science and mathematics courses, including more than one discipline, into different branches (Riechert \& Post, 2010). STEM education aims to teach science, mathematics, engineering, and technology, which includes lifelong education activities suitable for all grade levels starting from pre-school to post-doctorate. However, it seems that the renewed curriculum in Turkey mentions STEM education under the name of science and engineering applications. It takes place from 4th grade to 8th grades (Hiğde, 2018), whereas STEM education can be applicable for all grades. Also, in the literature, not only in Turkey, a few studies are focusing on third graders. Because this study focuses on third graders, it makes this study significant.

In order for countries to keep up with technological and scientific developments in the world and to be among the

Received: 17 March 2020

Revised: 20 June 2020

Published: 28 July 2020 
developed countries, it needs individuals with an entrepreneurial spirit who are interested in STEM fields and can think innovatively. Meeting this need is possible with an education system that enables students to take responsibility, allow them to make mistakes, enable them to produce everyday products, enable them to think and produce. It is evident that the developing countries need STEM education, and their curricula should be rearranged to include entrepreneurship, art design, and programming (Akgündüz et al., 2015, Ültay \& Ültay, 2020). STEM education increases competitiveness between countries and supports countries' social and economic development (Çakmakç1, 2016). Another aim of STEM education is to raise individuals who will contribute to the industrialization of countries and to make countries economically and industrially developed countries (Çevik \& Özgünay, 2018).

Although STEM is understood in different ways in the world, the common characteristics of all are bringing together different disciplines and applying them to the problems we may encounter in daily life as a result of using the integration of concepts and skills together. STEM education includes the knowledge, skills, and opinions that arise from the point where two or more subject areas are integrated (Çorlu, Capraro, \& Capraro, 2014). In STEM education, it is aimed that individuals can solve problems, think in many ways, be confident, transfer technology to learning, and develop creative and communication skills (Bybee, 2010; Morrison, 2006). Morrison (2006) listed the skills that individuals should acquire with STEM education as follows: Innovative, problem solving, inventing, selfconfidence and self-motivation, consistent thinker, and technology literate. STEM education should be able to improve students' characteristics, such as understanding how the equipment works and using technology well (Bybee, 2010). In STEM education, there is a presentation of a problem that students may encounter from daily life within a particular context. Students should also design and produce a solution proposal for this problem (Ültay \& Ültay, 2020). These designs may be technological or engineering-based (Felix, 2016). STEM education is planned to gain skills such as inquiry, research, problemsolving, communication, and teamwork to individuals. STEM education should include activities that attract attention and make the individual eager to learn (Baran, Canbazoğlu Bilici, \& Mesutoğlu, 2015).

When looking at some studies on STEM, it is seen that Yamak, Bulut, \& Dündar (2014) examined the effects of STEM-based activities on 5th-grade students' attitudes towards scientific process skills and science education. The study concluded that STEM activities positively improved students' attitudes towards scientific process skills and science education. In the study of Cotabish, Dailey, Robinson, \& Hughes (2013), students and teachers from the 2 nd to 5 th grade participated in the study, and it was found that the control group was more successful compared to the control group in terms of the science process skills, science concepts, and science content knowledge. Also, they found that the students who participated in STEM education were also more successful. Park \& Yoo (2013), found that teaching the subject of light with 6th-grade students with a STEAM (STEM+Art) approach provided a definite increase in students' interests and motivations, but could not detect a significant difference in their scientific process skills. Kong \& Huo (2014) examined STEAM education's effect on 4th-grade students' attitudes towards science, self-efficacy, and science self-efficacy. However, there was no significant difference between the groups; the average of the experimental group students was higher than the control group. Karahan, Canbazoğlu Bilici, \& Ünal (2015) aimed to determine 8th-grade students' attitudes towards science lesson and their views on STEM approach with their STEM activities. As a result of the research, it was stated that the students understood the science lesson better, the lesson became more enjoyable and contributed to their teamwork skills.

Yildirım \& Altun (2015) examined the effect of STEM education and engineering practice on academic success in the Science and Technology course. In the quasiexperimental model conducted with the pre-service science teachers who constitute the study group of the research, a significant difference was found in favor of the experimental group where STEM education and engineering education were applied, and it was concluded that it affects the academic success of the students positively. Gülhan \& S Sahin (2016) examined the effect of STEM integration on 5th-grade students' perceptions and attitudes in STEM fields. In the study in which quasiexperimental design was used, perception and aptitude tests revealed that STEM activities improved students' perception and attitudes towards STEM. Baran, Canbazoğlu Bilici, Mesutoğlu, \& Ocak (2016) implemented an out-of-school STEM education program for 6th-grade students. According to the results of the research, it was suggested that integrating STEM activities into the out-ofschool education program could support the development of students' interest in following their STEM-related careers. Knop et al. (2017) stated that within the scope of a five-day study conducted with 31 secondary school students, designing interactive robots in STEM education on students' attitudes was examined, and their opinions were received. As a result of the study, they observed that the students' interest and attitude towards STEM increased and emphasized that they attracted the students' attention. In the study, in which Azgin \& Şenler (2019) took 3rdgrade and 4th-grade students as a sample, it was aimed to examine students' STEM career interests and attitudes towards STEM in terms of some variables. As a result of the study, it was determined that male students' STEM career interests were higher than female students, and 
STEM attitude scores did not differ significantly between male and female students.

As can be understood from meta-analysis and metasynthesis studies for STEM education, most of the studies focus on teacher education and secondary and postsecondary levels (Becker \& Park, 2011; Herdem \& Ünal, 2018). The studies carried out at the primary school level are very few and generally at the 4th-grade level. In this sense, the study can make useful contributions to the related field.

As mentioned above, STEM education focuses on 21stcentury skills such as critical thinking, creativity, innovation, etc. According to Choe (2006), scientific creativity has recently become an essential educational target and a social issue for nations' welfare. From this point of view, determining the creative thinking of students is essential in terms of education. Morrison (2006) describes the students who take STEM education as 'inventors' because they become aware of the needs of the world and find and implement creative solutions. In addition, not only creativity but also all 21 st-century skills are considered very important for students because they are also signals of people who will improve the countries for further. From this point of view, the study aimed to examine the effect of teaching "Let's Know the Matter" unit with a $5 \mathrm{E}$ instructional model accompanied by STEMfocused activities on grade 3 students' academic success and their opinions about STEM.

\section{METHOD}

As this study aimed to determine the effect of teaching the "Let's Know the Matter" unit based on the 5E instructional model accompanied with STEM-focused activities, it does not have only the quantitative dimension. It also has a qualitative study since it aims to determine students' thoughts about STEM teaching. In this study, one group pretest-posttest research design was used. Onegroup pretest-posttest research design can be used to determine the effect of an implementation (Allen, 2017). In this study, the effect of the $5 \mathrm{E}$ instructional model accompanied by STEM-focused activities was researched, and also, students' opinions about STEM was tried to be revealed.

\subsection{Study Group}

The study group of the research consisted of 24 students studying at the 3rd grade level of a primary school affiliated to the Ministry of Education in the Central district of a province in the Eastern Black Sea Region of Turkey in the academic year 2019-2020. The students' age was between 8 and 9.12 of the students were female, and 12 of them were male students. Students were coded as S1, $\mathrm{S} 2, \ldots, \mathrm{S} 24$.

\subsection{Data Collection Tools}

The "Let's Know the Matter" unit, which is the 4th unit of the 3rd-grade science course, was taught to students in a total of 17 lesson hours, based on 5E instructional model accompanied with STEM activities, following the program. Before the application started, "Let's Know the Matter Test (MT)" was applied as a pre-test to measure the students' pre-knowledge. Multiple choice test was preferred as a measurement tool to get more objective results. Also, students' ages range between 8-9, and because of their ages, they were very active in the classroom, and as observed in the activities, they were bored quickly. The researchers decided the way to get the most reliable results without boring them was to perform multiple-choice testing. MT contains 20 multiple choice test items. Discrimination and difficulty indices for each item are given in Appendix 1. The researchers prepared MT under unit acquisitions. The pre-application for validity and reliability analyzes was carried out with a group of 3rd-grade students (30 students) different from the application group. In the pilot application, the reliability coefficient of the test (Cronbach alpha) was 0.737 , and in the application of the study group, it was 0.741 . For content validity, opinions were received from six primary teaching educators and a primary school teacher, and the opinion that the scope validity was obtained as appropriate. Also, opinions on the suitability of the structure and appearance validity were taken from two science education experts. After the application, MT was reapplied as a post-test. Two sample questions from MT are presented below:

2. Which of the following items has a smooth surface?

A) Mirror

B) Carpet

C) Sofa

4. In which of the following are all substances liquid?

A) Cologne, Water, Olive Oil

B) Air, Fruit Juice, Soda

C) Syrup, Milk, Fruit

After the application ended, the researchers asked students who were volunteers to interview, and five students were volunteers. Then, open-ended questions were asked to these five volunteer students to reveal students' opinions on STEM activities. The questions were constructed by the researchers and were collected from the students through a semi-structured interview technique. The interviews lasted for approximately 10-15 minutes and were recorded with the voice recorder by obtaining the consent of the students.

\subsection{Data Analysis}

The data obtained from the MT, which was applied as a pre-test and post-test, were scored "1 (one)" for correct answers, and false/empty answers were scored "0 (zero)". The first condition for using parametric testing in data analysis is to implement the application with at least 30 participants. Since the number of students participating in the application was below 30, it was deemed appropriate to perform analysis with non-parametric tests. The total 
scores obtained from MT were analyzed with the Mann Whitney U test, one of the non-parametric tests with the help of the Statistical Package for the Social Sciences, and is shown in the findings section with tables. In addition, the data obtained from semi-structured interviews applied to reveal students' opinions on STEM activities were transcribed first, and appropriate categories were identified under common themes after necessary reductions were made.

\subsection{Validity and Reliability}

Researchers created the MT used in the application, a pilot study was applied to a group of similar features for reliability analysis, and the reliability coefficient (Cronbach Alpha) was calculated to be 0.737. Apart from this, the scope validity was obtained by the opinions of six classroom education experts and a classroom teacher regarding whether the MT test questions and interview questions asked following the acquisitions cover the subject area. Structure and appearance validity of data collection tools were tried to be obtained by taking the opinions of two science education experts.

In the classroom where the researchers are conducting the research, many STEM applications have been made in the 'Science' course before this application by different researchers. From this point of view, the applied group is accustomed to being taught with STEM-focused activities. In this application, the teacher of the class participated as an audience. Thus, an environment was tried to be created for students to feel safer and more comfortable. The implementation was carried out by the researchers who are also the authors of this manuscript. Because the teacher had not information and experience about STEM and its implementation, the researchers who were studying for STEM in a primary school in the master of education programs, the researchers carried out the implementation under the supervisory of the first author.

\subsection{Implementation}

The research aims to teach "Let's Know the Matter" unit with STEM-focused activities, and lesson plans are prepared according to the $5 \mathrm{E}$ model. The first step of $5 \mathrm{E}$ is to enter/engage in which students' attention is directed towards the related topic, and their pre-existing knowledge is stimulated. The second step of $5 \mathrm{E}$ is exploring where the students make an observation, use their pre-knowledge, conduct experiments, and discover new knowledge. The third step of $5 \mathrm{E}$ is to explain in which students ask the teacher to disconfirm/confirm the students' gained knowledge. The fourth step of $5 \mathrm{E}$ is elaborate in which students elaborate their acquired knowledge within interdisciplinary or interrelated concepts. The final step of $5 \mathrm{E}$ is evaluating in which students evaluate what they learned. The first lesson plan prepared with the $5 \mathrm{E}$ model is in Appendix-2.

At the beginning of the implementation, students were divided into six groups of 4 and 5 people. Later, the students were pre-tested, and their prior knowledge was determined. The activities in the lesson plan were administered to the students, respectively. First of all, various activities were held in the course to explain the "Characteristics of the Matter." In the first activity of this subject, which lasted for 11 lessons, one student was selected from the groups. The eyes of the selected student were closed with a cloth. The student was asked to take one of the objects in the previously prepared boxes, and the student described the properties of this object and tried to guess the object. This activity continued until there were no objects in the box. After this activity, another activity (Let us learn) was made in the exploration phase, and various materials were given to the student groups. After the students examined the distributed materials, they wrote the properties of the objects. Then, researchers asked various questions about objects (for example, what do you feel when you touch it? Does this matter shine a light?). Videos were watched from various websites on the subject (e.g., EBA, Okulistik, etc.). In the third activity, "What are the characteristics of that matter?" game was played with the students. Visuals about the activity are given in Appendix3. In the explanation step, the fourth activity was made with "Dramatization" worksheets prepared in accordance with the acquisition of "touching, looking at, tasting, tasting, and smelling some substances may harm the living body." Worksheets are distributed to groups.

The students read these dramas with their groups, answered the questions written under the drama, and expressed their solutions through the group representative. An example of worksheets is given in Appendix-4. In the fifth activity, volunteer students played the dramas written. From the characteristics of the matter, the student chose a feature. The feature that the student chose was written on his collar, and the badges were hung. Phrases such as 'Hard matter, introduce yourself' were established. The student put this feature in his place, introduced the feature of the chosen item with his sentences. In the elaboration stage, in the sixth activity, it was tried to explain whether the items were rough or smooth. In this activity, students told their properties by touching the objects around. Subsequently, the items given were asked to smooth the rough ones, and smooth ones to be roughened. For this, sanding paper and rough wood pieces, aluminum foil, etc. were given to the groups. Visuals about the activity are given in Appendix-5. The STEM-focused activity was started in the seventh activity in the elaboration stage. The text and studies for STEM activity are given in Appendix-6. In the evaluation phase, the last activity of the subject was made. In the activity, students were asked to make a poster study on the properties of matter. Poster works are shown in Appendix7.

After the subject of ' Characteristics of the Matter ', the subject of 'States of the Matter', which will take 6 lesson hours, was started. For this subject area, a lesson plan with 
the $5 \mathrm{E}$ model was prepared. The prepared lesson plan is given in Appendix-8. In this subject area, "Do you know my features?" activity was made. In this activity, different items were placed on the table. The students were asked to examine them and talked about their features. In the second activity, different materials were put into three gloves. A glove was filled with water, a glove was filled with stones, and the other was inflated with air. The students were asked about the differences between the gloves and asked to explain their reasons. A section from the cartoon was watched, and students were asked about the items they saw in the cartoon. Their attention was drawn by asking riddles. The riddles asked are in Appendix-9. In the third activity, the starch-water experiment was done to understand the concepts of solid and liquid. The experiment carried out is in Appendix-10. In the fourth activity, the wind was blown to understand the concept of gas, and then they were asked to cool their cartons by shaking them to their friends, and they were made fan. It was provided to the students the balloons to be inflated and had made them feel the gas exit from the balloon by touching their cheeks.

In the fifth activity, students did breathing exercises. In the explanation part of the course, students were given information about the states of matter. After the explanation, the students read the story text to be used in the STEM activity, and questions were asked. The story text is given in Appendix-11. Students were asked to design and create a new product according to the given text. In this process, students were helped by asking questions at a level where they could have improved their products. The resulting products are shown in Figure 1. At the evaluation stage of the lesson, the game prepared for the students was played. The game is given in Appendix-12. The game was as follows: The students were ranked among themselves, and the game started. The student rolled the dice and advanced the box by the number of dice that he threw his pawn. The student said in what form the word, in the box it came from. If he said it wrong, it passed to the other student. If he answered the question correctly, he brought points to his group. In the last stage of the course, after the implementation of the $5 \mathrm{E}$ model, open-ended questions were asked to 5 volunteer students for qualitative evaluation. The post-test was administered, and the implementation was finished. The implementation lasted for 17 lesson hours in 6 weeks.

\section{RESULT AND DISCUSSION}

This study aimed to determine the effect of teaching third-grade students based on the 5E instructional model accompanied with STEM-focused activities on the "Let's Know the Matter" unit and to determine the thoughts of the students about STEM teaching data was collected for this purpose. MT was applied as a pre and post-test to measure the success of students. The findings obtained as a result of analyzing the data obtained from MT with the Mann Whitney $U$ test are presented in Table 1.

According to Table 1, in the implementation of "Let's Know the Matter" unit, which is taught based on the $5 \mathrm{E}$ instructional model accompanied by STEM-focused activities, MT was administered as a pre and post-test on the subject. According to the table, while the pre-test point average of the group was 17.31, the post-test point average

Table 1 Findings from the analysis of the data obtained from MT with the Mann-Whitney U test (N: 24)

\begin{tabular}{llllll}
\hline MT & $\mathbf{N}$ & $\mathbf{X}$ & $\begin{array}{l}\text { Std. } \\
\text { Dev. }\end{array}$ & $\mathbf{U}$ & $\mathbf{P}$ \\
\hline Pre Test & \multirow{2}{*}{24} & 17,31 & 3,10 & 115,50 &, 00 \\
Post Test & & 31,69 &, 51 & & \\
\hline
\end{tabular}

Table 2 Students' answers to the interview questions

\begin{tabular}{llc}
\hline \multicolumn{2}{l}{ Question 1: How did you find the activities done in this lesson? } & \\
\hline Themes & Students & $f$ \\
It was nice, it was fun. & S5, S17, S19 & 3 \\
It was instructive. & S16, S20 & 2 \\
\hline Question 2: What was your favorite section in the implementation? & Students & $f$ \\
\hline Themes & S5, S16, S19, S20 & 4 \\
Shipbuilding & S17, S20 & 2 \\
All of STEM activities & Students \\
\hline Question 3: Was there any part you had difficulty in the activities? If yes, which part? & $f$ \\
\hline Themes & S5, S19, S20 & 3 \\
There was complexity when making ships. & S16, S17, S20 & 3 \\
It was difficult for the planning phase of STEM activities. & $f$ \\
\hline Question 4: Were there any parts you did not like in the activities? Explain why you don't like it. \\
\hline Themes & Students \\
There was no part I did not like. & S16, S17, S19, S20 \\
The starch experiment is not liked. & S5 & 4 \\
\hline Question 5: Would you like to learn other subjects in this way in science class? & 1 \\
\hline Themes & Students \\
Yes, I would. it was fun. & S5, S16, S17, S19, S20 \\
\hline
\end{tabular}


was 31.69. As can be seen from the table, as a result of the analysis, it is seen that the subject taught with a $5 \mathrm{E}$ instructional model accompanied by STEM-focused activities creates a significant difference in the success of students $(115.50, \mathrm{p}<.05)$.

After the post-test application, semi-structured interviews were done with five volunteer students. The data obtained through the semi-structured interview form was edited and presented in Table 2. The names of the students were kept confidential and given with their code.

Question 1 was asked about how students found the activities and the findings were presented in Table 2. As can be seen from the answers given to the question, the students stated that they liked the lesson's activities. Student coded S5 said, "I like it because it was fun and nice." Question 2 was asked to find out what sections they liked most in the activities held for students, and S17 coded student said, "I like the activity sections, we build boats, I like to do different things. We were trying to come in front of the board, touch something, and guess them. We were doing different experiments. STEM events were very nice". S20 coded student said, "I liked the sections where we designed something for STEM activities the most. I loved making ships," she stated her opinion. The ship samples that the students made within the scope of STEM activities are shown in Figure 1. Examples of products developed by students to protect from rain are also shown in Figure 2.

The third question was asked to students to find out if there were any difficulties in their activities. The findings are presented in Table 2 . As can be seen from their answers to the question, there have been problems in shipbuilding and planning parts of STEM activities. An S5-coded student answered as "It was a little complicated when we were making a ship." The student coded S16 said, "There was confusion because we had no idea."

Similarly, the student coded S20, similar to the student with the code of S16, said, "There were places where I had difficulty. We had difficulties most during the planning phase. For example, it was difficult to plan how to make the ship." Question 4 was asked to find out if there were any parts of the activities that students did not like, and S5coded student said that "I did not like the starch experiment because my hands were sticky." Apart from this, other students stated that they liked all of the activities. Question 5 was asked to students to find out if they would

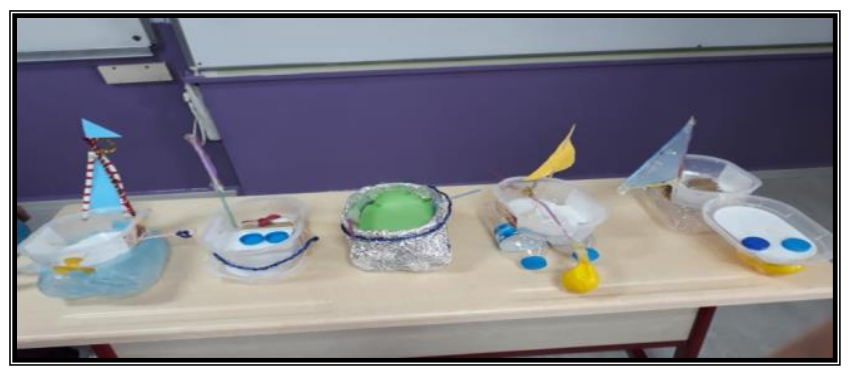

Figure 1 Ship samples designed by students like other subjects to be covered based on STEM-focused activities in a science lesson, and S20 coded student said, "Yes, I would. It both entertains and keeps it in our minds." Similar answers were received from other students.

This study was carried out to determine the effect of teaching in the 3rd grade "Let's Know the Matter" unit with a 5E instructional model accompanied with STEM-focused activities on students' academic achievement and to get their opinions about STEM activities during 17 lesson hours. As a result of the study, a significant increase was observed in students' achievements. Similar studies on the impact of STEM activities on success have also been shown the contribution to academic success (Herdem \& Ünal, 2018). Traditional learning in science education based on direct instruction and books is not effective in students' learning concepts (Akçam, Dökme, \& Tunç, 2011; Ültay, 2012). Thus, some students stated in the interview (in Table 2) the lessons were instructive. They were aware that they had learned better with the 5E instructional model accompanied with STEM-focused activities. Therefore, STEM studies are of great importance in education. Also, STEM activities develop positive attitudes among students (Ültay, Emeksiz, \& Durmuş, 2020). It broke the prejudice against science lessons created by students and raised their interest and attitudes towards this area (Gülhan \& Şahin, 2016). In other words, students have a negative attitude towards science lessons, and STEM studies broke this prejudice and brought a positive attitude to it (Aydın, Guzey, \& Saka, 2017; Yamak, Bulut, \& Dündar, 2014). In the interview, the students stated that they wish all courses to be taught with STEM. The reason for this, their interest and motivation were always alive during the courses. Thus, their attitudes were affected positively.

This study also contributed to the field in terms of seeing how much STEM activities affect the teaching of "Let's Know the Matter" unit. Between the pre and posttest results after the application, it was seen that STEM activities increased the students' success in terms of learning the "Let's Know the Matter" unit. In other words, students were able to learn the "Let's Know the Matter" unit effectively with the $5 \mathrm{E}$ instructional model

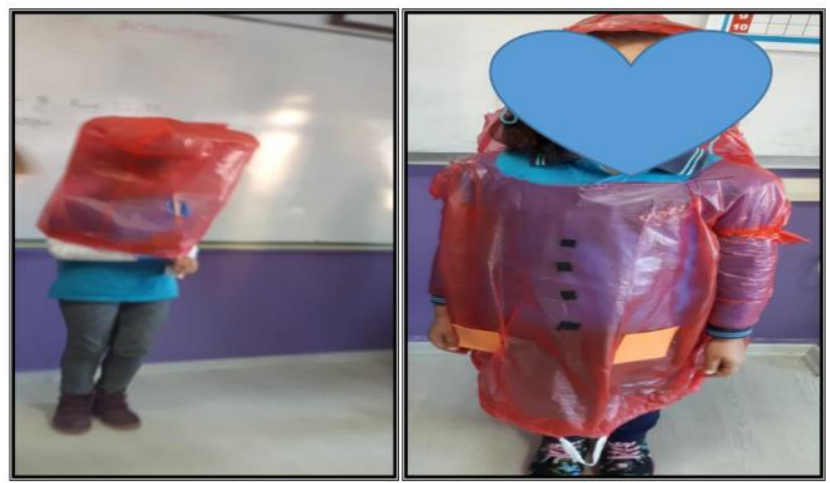

Figure 2 Examples of raincoats developed by students to protect from rain 
accompanied with STEM-focused activities. This result can be arisen from using not only STEM-focused activities but also the $5 \mathrm{E}$ instructional model. $5 \mathrm{E}$ instructional model is a well-known model to attract students' interest by associating the content knowledge to the daily life examples (Er Nas, Çoruhlu, \& Çepni, 2010; Ültay \& Çalık, 2011). Furthermore, using the $5 \mathrm{E}$ instructional model accompanied with STEM-focused activities had probably more motivated students than using STEM-focused activities alone. In particular, STEM-focused activities were prepared by considering students' interests, such as designing a raincoat. These activities also motivated students during the whole lesson, and their academic successes were also improved. This result is similar to some of the studies' results in the literature. Many studies have found that teaching based on STEM activities contributes to students' academic success (Aydın, Guzey, \& Saka, 2017; Ercan \& Şahin, 2015; Wade-Shepherd, 2016).

\section{CONCLUSION}

It has been revealed that elementary school students have many misconceptions or misleading for different reasons (Gödek \& Polat, 2017). Along with the teachings made with STEM activities, students can correct their wrong information by testing their knowledge. Also, teachings made with STEM activities lead students to learn, research, and question. STEM activities are concerned not only with existing problems but also with probable problems (Tabaru, 2017). In this respect, this study focused on the problems that umbrellas and ship models made by students can encounter in daily life. The problems that they may encounter in daily life have been narrated, and students have the feeling of developing solutions for these problems. For example, a child who caught a little fish on the shore with his father wanted to sail with his father, and students decided to build a boat to help this child. Later, the students were divided into groups, and as a result, different materials emerged to solve the problem. Also, students realized that teamwork is essential in STEM activities for reasons such as acting together as a group and supporting each other. The gathering of students within the scope of STEM activities leads to the development of communication and cooperation between individuals (Choi \& Hong, 2013; Kim, Ko, Han, \& Hong, 2014).

At the end of the study, five open-ended questions were asked to five students, and the students' opinions about STEM activities were determined. Tables were examined for this situation, and some conclusions were reached. For example, all of the students stated that they liked STEM activities. This result is compatible with many studies (Damar, Durmaz, \& Önder, 2017; Karakaya, Yantır1, Yılmaz, \& Yılmaz, 2019; Ültay, Emeksiz, \& Durmuş, 2020). Also, another striking result obtained in the interview is that students' favorite parts are STEM activities. At the same time, the most challenging stage is the planning stages of STEM activities such as shipbuilding. The reason for this may be the anxiety that students experience about how to use the materials. In their study, Akgündüz \& Akpinar (2018) stated that the students' most challenging stage is the design phase of the products. Eroğlu \& Bektaş (2018) also stated that the lack of information about the products and target behaviors that the students will design prevent the efficiency of STEM activities.

Another result obtained from the research is that students want to learn other courses in this way. This situation may be the result of the active participation of the students in the lesson, the effectiveness of their learning performance, and the pleasure of the students in producing the products. The contribution of STEM activities to the creativity of students and the development of their imagination is also known (Hiğde, 2018). It also improves the skills of producing solutions to daily life problems (Karakaya, Yantır1, Yılmaz, \& Yılmaz, 2019; Roberts, 2012). However, it also coincides with other studies in which students love to learn science subjects through experiments or have fun activities (Ültay \& Alev, 2017; Ültay, Durukan, \& Ültay, 2014).

Based on the results obtained from the research, it may be suggested to use STEM activities for teaching other subjects due to the positive behavior and thoughts of the students about STEM activities. Especially considering that the vast majority of STEM-focused studies in the literature started from the 4th grade, subject teaching with STEM activities can also be recommended for younger age groups. The reason for this can be said that the foundations of the scientific process skills required during the STEM activities are formed at a young age. In addition, the concept and academic success can be explored in studies conducted with STEM.

\section{REFERENCES}

Akçam, H. K., Dökme, İ., \& Tunç, T. (2011). Üç aşamalı sorularla sınıf öğretmeni adaylarının bazı temel fen kavramları hakkında sahip oldukları kavram yanılgıları [Primary school teacher candidates' misconceptions on some fundamental science concepts with three annotated questions]. Gazi University Gazi Education Faculty Journal, 31(2), 817-842 (In Turkish).

Akgündüz, D., \& Akpınar B. B. (2018). Okul öncesi eğitimde fen eğitimi temelinde gerçekleştirilen STEM uygulamalarını öğrenci, öğretmen ve veli açısından değerlendirilmesi [Evaluation of STEM applications based on science education in pre-school education in terms of students, teachers, and parents]. Journal of Education for Life, 32(1), 1-26 (In Turkish).

Akgündüz, D., Aydeniz, M., Çakmakçı, G., Çavaş, B., Çorlu, M.S., Öner, T. \& Özdemir, S. (2015). STEM eğitimi Türkiye raporu [STEM Education Turkey report]. Scala publishing (In Turkish).

Allen, M. (Ed.). (2017). The SAGE encyclopedia of communication research methods. SAGE Publications.

Aydın, G., Guzey, S., \& Saka, M. (2017). 4-8. sınıf öğrencileri fen, teknoloji, mühendislik, matematik (STEM = FETEMM) tutumlarının incelenmesi [Science, technology, engineering, mathematics (STEM) attitude levels in grades 4th -8 th]. Mersin University Education Faculty Journal, 13(2), 787-802 (In Turkish).

Azgın, A. O., \& Șenler, B. (2019). İlkokulda STEM: Öğrencilerin kariyer ilgileri ve tutumları [STEM in primary school: Students' career 
interest and attitudes]. Journal of Computer and Education Research, 7(13), 213-232 (In Turkish).

Baran, E., Canbazoglu Bilici, S., Mesutoglu, C., \& Ocak, C. (2016) Moving STEM beyond schools: Students' perceptions about an out-of-school STEM education program. International Journal of Education in Mathematics, Science and Technology, 4(1), 9-19.

Baran, E., Canbazoğlu Bilici, S., \& Mesutoğlu, C. (2015). Fen, teknoloji, mühendislik ve matematik (FeTeMM) spotu geliştirme etkinliğ [Science, technology, engineering, and mathematics (STEM) public service announcement (PSA) development activity]. Journal of Inquiry Based Activities, 5(2), 60-69 (In Turkish).

Becker, K., \& Park, K. (2011). Effects of integrative approaches among science, technology, engineering, and mathematics (STEM) subjects on students' learning: A preliminary meta-analysis. Journal of STEM Education: Innovations \& Research, 12(5-6), 23-37.

Bybee, R.W. (2010). What is STEM education? Science, 329, 996.

Choe, I. S. (2006). Creativity-A sudden rising star in Korea. In J. C. K. Kaufman \& R. J. Sternberg (Eds.), (pp. 395-420). Cambridge University

Choi, Y., \& Hong, S.H. (2013). The development and application effects of steam program about 'world of small organisms' unit in elementary science. Elementary Science Education, 32(3), 361-377.

Cotabish, A. Dailey, D., Robinson, A., \& Hughes, G. (2013). The effects of a STEM intervention on elementary students' science knowledge and skills. School Science and Mathematics, 113(5), 215- 226.

Çakmakçı, G. (2016, April 14). Dünya ile rekabet için STEM şart [STEM is essential for competition with the world]. Hürriyet. http://www.hurriyet.com.tr/dunya-ile-rekabet-icin-stem-sart40087941 (In Turkish)

Çevik, M., \& Özgünay, E. (2018). STEM education through the perspectives of secondary schools teachers and school administrators in Turkey. Asian Journal of Education and Training, 4(2), 91-101.

Çorlu, M. S., Capraro, R. M., \& Capraro, M. M. (2014). Introducing STEM education: Implications for educating our teachers for the age of innovation. Education and Science, 39(171), 74-85.

Damar, A., Durmaz, C., \& Önder, İ. (2017). Middle school students' attitudes towards STEM applications and their opinions about these applications. Journal of Multidisciplinary Studies in Education, 1(1), 47-65.

Er Nas, S., Coruhlu, T. S., \& Cepni, S. (2010). An assessment on the effectiveness of the material developed for the elaborate stage of the 5E model. Journal of Ondokuz Mayıs University Faculty of Education, 29(1), 17-36 (In Turkish).

Ercan, S., \& Şahin, F. (2015). Fen eğitiminde mühendislik uygulamalarının kullanımı: Tasarım temelli fen eğitiminin ögrencilerin akademik başarıları üzerine etkisi [The usage of engineering practices in science education: effects of design based science learning on students' academic achievement]. Necatibey Faculty of Education Electronic Journal of Science and Mathematics Education, 9(1), 128-164 (In Turkish).

Eroğlu, S., \& Bektaş, O. (2016). STEM eğitimi almış fen bilimleri öğretmenlerinin STEM temelli ders etkinlikleri hakkındaki görüşleri [Ideas of science teachers took STEM education about STEM based activities]. Journal of Qualitative Research in Education, 4(3), 43-67 (In Turkish).

Felix, A. (2016). Design based science and bigher order thinking [Doctoral Dissertation, Virginia Polytechnic Institute and State University]. VirginiaTech.

Gödek, Y., \& Polat, D. (2017). Fen eğitiminde kavram öğretimi [Concept teaching in science education]. In D. G. Mutlu Pinar, Fen Bilimleri Ögretimi [In Science Teaching] (s. 48-70). Pegem Publishing (In Turkish).

Gülhan, F., \& Şahin, F. (2016). Fen-teknoloji-mühendislik matematik entegrasyonunun (STEM) 5. sınıf öğrencilerinin bu alanlarla ilgili alg1 ve tutumlarina etkisi [The effects of science-technologyengineering-math (STEM) integration on 5th grade students' perceptions and attitudes towards these areas]. International Journal of Human Sciences, 13(1), 602-620 (In Turkish).

Herdem, K., \& Ünal, İ. (2018). STEM eğitimi üzerine yapılan çalıșmaların analizi: Bir meta-sentez çalıșması [Analysis of studies about STEM education: A meta-synthesis study]. Marmara University Atatïrk Education Faculty Journal of Educational Sciences, 48, 145-163 (In Turkish).

Hiğde, E. (2018). The Investigation of the effect of the STEM activities prepared for 7 th class students in terms of different variables [Unpublished doctoral dissertation]. Aydın Adnan Menderes University.

Karahan, E., Canbazoğlu Bilici, S., \& Ünal, A. (2015). Integration of media design processes in science, technology, engineering, and mathematics (STEM) education. Eurasian Journal of Educational Research, 60, 221-240.

Karakaya, F., Yantırı, H., Yılmaz, G., \& Yılmaz, M. (2019). İlkokul öğrencilerinin STEM etkinlikleri hakkında görüşlerinin belirlenmesi: 4. sınıf örneği [Determination of primary school students' views about STEM activities: Example of 4th grade]. International Journal of Turkish Education Sciences, 7(13), 1-14 (In Turkish).

Kim, D. H., Ko, D. G., Han, M. J., \& Hong, S. H. (2014). The effects of science lessons applying STEAM education program on the creativity and interest levels of elementary students. Journal of the Korean Association for Science Education, 34(1), 43-54.

Knop, L., Ziaeefard, S., Ribeiro, G. A., Page, B. R., Ficanha, E., Miller, M. H., \& Mahmoudian, N. (2017). A human-interactive robotic program for middle school stem education. 2017 IEEE Frontiers in Education Conference (FIE) (pp. 1-7). IEEE.

Kong, Y. T., \& Huo, S. C. (2014). An effect of STEAM activity programs on science learning interest. Advanced Science and Technology Letters, 59, 41-45.

Morrison, J. (2006). Attributes of STEM education: The student, the school, the classroom. TIES (Teaching Institute for Excellence in STEM), 20, 2-7.

Park, S. J., \& Yoo, P. K. (2013). The effects of the learning motive, interest and science process skills using the 'Light' unit on sciencebased STEAM. Journal of Korean Elementary Science Education, 32(3), 225-238.

Riechert, S., \& Post, B. (2010). From skeletons to bridges and other STEM enrichment exercises for high school biology. The American Biology Teacher, 72(1), 20-22.

Roberts, A. (2012). A justification for STEM education. Technology and engineering teacher, 71(8), 1-4.

Sanders, M. (2009). STEM, STEM education, STEMmania. The Technology Teacher, 68(4), 20-26.

Tabaru, G. (2017). İlkokul 4. sme ögrencilerine fen bilimleri dersinde uygulanan STEM temelli etkinliklerin çeșitli değiskenlere etkisi Elementary school 4th grade the effects of stem-based activities applied in science lessons to primary education students in terms of various variables] [Unpublished master thesis]. Niğde Ömer Halisdemir University (In Turkish).

Ültay, E. (2012). Implementing REACT strategy in a context-based physics class: Impulse and momentum example. Energy Education Science and Technology Part B: Social and Educational Studies, 4(1), 233240.

Ültay, E., \& Alev, N. (2017). Investigating the effect of the activities based on explanation assisted REACT strategy on learning impulse, momentum and collisions topics. Journal of Education and Practice, 8(7), 174-186.

Ültay, N., \& Çalık, M. (2011). Distinguishing 5E model from REACT strategy: An example of 'Acids and Bases' topic. Necatibey Faculty of Education Electronic Journal of Science and Mathematics Education, 5(2), 199-220.

Ültay, N., Durukan, Ü. G., \& Ültay, E. (2014). Determination of student teachers' views about REACT strategy. ICEMST 2014: International Conference on Education in Mathematics, Science \& Technology, The Eurasia Proceedings of Educational \& Social Sciences (EPESS) 1, 298-302.

Ültay, N., Emeksiz, N., \& Durmuş, R. (2020). STEAM yaklaşımına ilişkin örnek bir uygulama ve uygulama hakkında öğrenci görüşleri 
[An example STEAM implementation and student opinions about the implementation]. Journal of Science Teaching, 8(1) 1-17 (In Turkish).

Ültay, N., \& Ültay, E. (2020). A comparative investigation of the views of pre-school teachers and teacher candidates about STEM. Journal of Science Learning, 3(2), 67-78.

Wade-Shepherd, A. A. (2016). The effect of middle school STEM curriculum on science and math achievement scores [Doctoral Dissertation, Union University]. ProQuest Dissertations And Theses.

Yamak, H., Bulut, N., \& Dündar, S., (2014). 5. Sinıf öğrencilerinin bilimsel süreç becerileri ile fene karşı tutumlarına FeTeMM etkinliklerinin etkisi [The impact of STEM activities on 5th grade students' scientific process skills and their attitudes towards science]. Gazi University Gazi Education Faculty Journal, 34(2), 249265 (In Turkish).

Yıldırım, B., \& Altun, Y. (2015). STEM eğitim ve mühendislik uygulamalarinin fen bilgisi laboratuar dersindeki etkilerinin incelenmesi [Investigating the effect of STEM education and engineering applications on science laboratory lectures]. El-Cezeri Journal of Science and Engineering, 2(2), 28-40 (In Turkish). 